\title{
Flows and budgets of nutrient salts and organic carbon in relation to a red tide in the Ria of Vigo (NW Spain)
}

\author{
Ricardo Prego \\ Instituto de Investigaciones Marinas, CSIC, Eduardo Cabello, 6, E-36208 Vigo, Spain
}

\begin{abstract}
In late September 1986, a major red tide occurred in the Ria of Vigo. Hydrographic conditions led to water retention, with circulation in a semi-closed circuit. In this study nutrient salts and carbon fluxes were calculated, and their consumption quantified, by use of a box model for the ria. The dinoflagellate Gymnodinium catenatum, scarcely present on 4 September, increased in concentration to

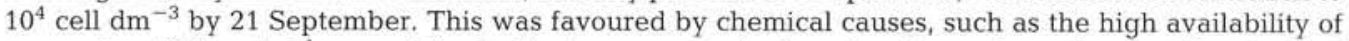
ammonium ( $6.2 \mathrm{~mol} \mathrm{~s}^{-1}$ were delivered to the upper water layer) and organic carbon, and by physical causes, such as the rapid circulation $\left(862 \times 10^{3} \mathrm{~kg} \mathrm{~s}^{-1}\right)$ with reducing mixing, almost half that of the preceding date. The nutrient salts came mostly from the remineralisation of organic matter. The amounts contributed by freshwater, $5 \%$ of the total, did not have an appreciable influence on the formation of the red tide. Vertical migration of the dinoflagellate played an important role. It is estimated that this organism was responsible for $22 \%$ of the synthesis of nitrogenous organic matter. The red tide came to an end with the November rains, which created rapid circulation which washed out the ria.
\end{abstract}

\section{INTRODUCTION}

The presence of red tides in late summer is common in the Rias Bajas of Galicia and, in particular, the Ria of Vigo. The first scientific description of a red tide in Galician waters was made by Sobrino (1918). Later Margalef studied a similar phenomenon, caused by a dinoflagellate of the genus Gonyaulax, during the summer of 1955 (Margalef 1956). He considered that this red tide was no more than the culmination of the last stage of phytoplankton succession observed in the ria of Vigo (Margalef et al. 1955) and was brought about by hydrographic conditions which assured sufficient water column stability for 2 or 3 wk.

It is only since 1976, coinciding with an important outbreak of paralytic shellfish poisoning in Europe (Luthy 1979), when toxicity was provoked by a red tide of the dinoflagellate Gymnodium catenatum (Estrada et al. 1984), that the subject has acquired great interest in the rias of Galicia. A consequence of this interest is an improved knowledge of the hydrographic conditions during red tides.

In late September 1986, a red tide was detected in the Ria of Vigo (Fraga et al. 1990). The concentration of
Gymnodium catenatum over time is indicated in Fig. 1. The conditions prior to this were normal for the summer (Mouriño et al. 1984) with a circulation pattern in 2 layers (Prego et al. 1990) typical for a partially stratified estuary (Beer 1983). The residual currents, or net advective horizontal flows $\left(F_{e}\right.$ and $F_{s}$ in Fig. 2), were strengthened by the upwelling caused by northerly winds (Prego \& Fraga in press). This situation was altered following a change in meteorological conditions (Fig. 1) to southerly winds and rain. Their effect on the ria was a retention of water and an unstable circulation in a semi-closed circuit (Fraga \& Prego 1989). An outline of this circulation is shown in section in Fig. 3.

The role that nutrient salts and organic matter may perform in red tides has scarcely been dealt with and precise information does not exist (Margalef 1989). In the course of a workshop on red tides, held in the I.E.O. (Instituto Español de Oceanografia) Centre in Vigo, the subject of the possible sources of ambient salts in a red tide was put forward (Prego unpubl.): contributions from rivers, from the exterior oceanic water, remineralisation and dinoflagellate migration. In this article, this subject is developed. The fluxes of 


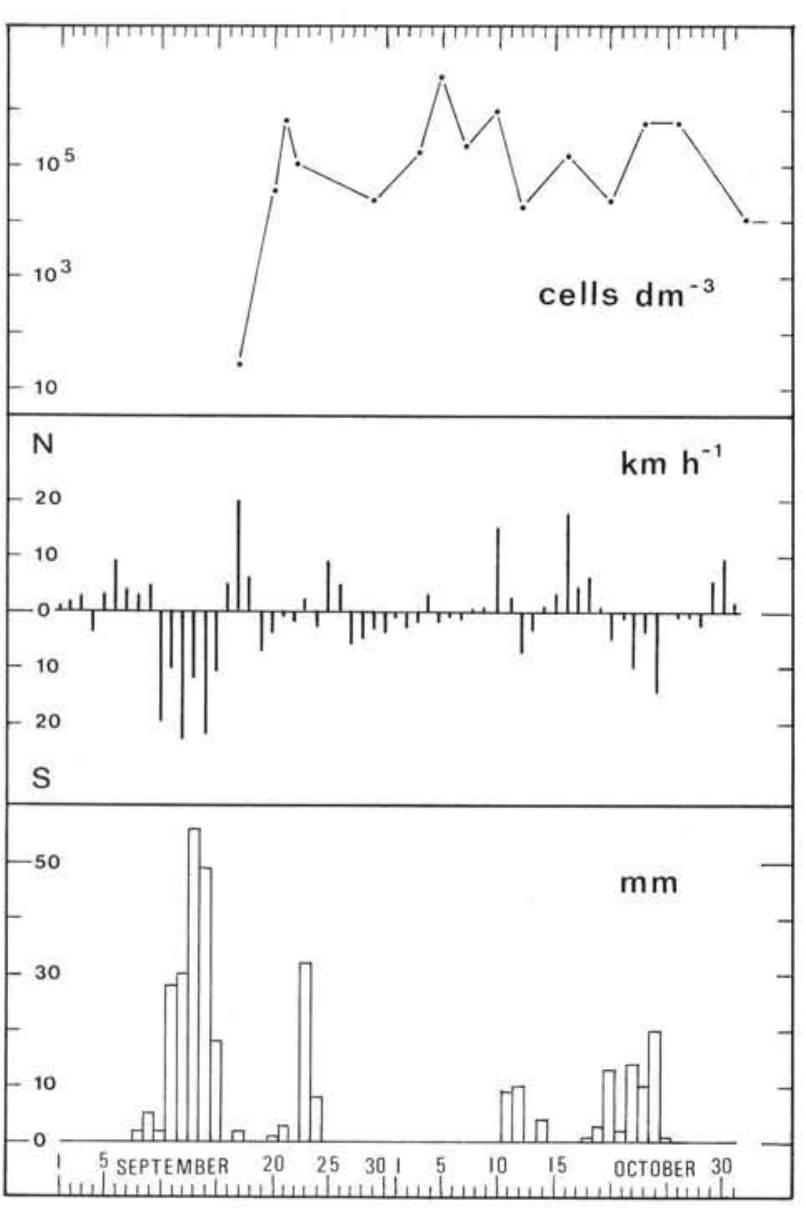

Fig. 1. Top: concentration of Gymnodinium catenatum at a station (near Stn 5 in Fig. 2) close to the mouth of the Ria of Vigo (data from Fraga et al. 1990). Middle: mean daily velocity of the northerly/southerly winds middle measured at Peinador (see Fig. 2). Botton: daily precipitation measured at Peinador (data from the Centro Meteorológico Zonal of La Coruna)

nutrient salts and organic carbon are calculated and their consumption in the conditions observed in the Ria of Vigo during the red tide of 1986 is quantified. Results show how high availability of recycled nutrients and raised hydrographic stability favour the evolution of red tides, in accordance with the model of Margalef (1978).

\section{MATERIAL AND METHODS}

The Ria of Vigo has an area of $156.21 \mathrm{~km}^{2}$ and is the most southerly of the rias of Galicia, which are situated in the northwest of the Iberian Peninsula. The zone under consideration in this study covers the inner and middle part of the ria up to Stn 3 (Fig. 2). On 4 and 21 September and 3 October, transects were carried out from the RV 'Garcia del Cid', taking samples of sea water in Niskin bottles at the stations indicated in Fig. 2 and at the depths marked in Fig. 3. Immediately after sampling, $50 \mathrm{ml}$ of water from each sample was taken and, without filtering, the following analyses were made using Technicon AutoAnalysers: nitrate (Mouriño \& Fraga 1985), nitrite, phosphate and silicate (Hansen \& Grasshoff 1983), ammonium (Grasshoff \& Johannsen 1972) and organic carbon (Prego \& Fraga 1988). These data were published in Prego et al. (1988).

A box model (Prego \& Fraga in press) was applied to the Ria of Vigo in order to calculate the water fluxes. The ria, or part of it, was considered as a box with 2 layers corresponding to the incoming $\left(\mathrm{F}_{\mathrm{e}}\right)$ and outgoing $\left(F_{s}\right)$ residual currents (Fig. 2). Vertical fluxes $\left(F_{d}\right.$ and $\left.F_{a}\right)$ occur between these layers. The difference between $F_{d}$ and $F_{a}$ is the incoming flux, $F_{e}$ and the lesser of them, $F_{d}$, is the mixing of water produced in the box. In this article, the box model is applied from Stns 1 to 3 (Fig. 2). Table 1 gives some characteristics of the box for the 3 study dates: the depth of the boundary between the layers where the velocity of residual current is zero $\left(\mathrm{F}_{\mathrm{e}}\right.$ and $F_{\mathrm{s}}$ have opposite directions), and the volumes of the layers. The calculation of water fluxes (F in Fig. 2) is considered on the basis of the contribution of fresh water, using salinity as a natural tracer, and on the circulation in 2 layers. Prego \& Fraga (in press) have determined these fluxes in stationary conditions, i.e. when the salinity of the water entering the ria from the ocean does not vary and the contribution of fresh water is constant. The calculated fluxes are summarised in Table 2.

\section{RESULTS}

\section{Flows of nutrient salts and carbon}

From the data for Stns 1, 2 and 3, the mean values of nitrate, nitrite, ammonium, phosphate, silicate and organic carbon in the upper and lower layer (see Fig. 2 inset) were calculated, averaging out the volume. From the data for Stn 3 (Fig. 2), mean values of the same parameters in the upper and lower portions of the section (vertical plane) at Stn 3 separating the estuarine and middle zones from the oceanic zone of the ria (Prego \& Fraga in press) were calculated, averaging out the surface area; the results are shown in Fig. 4.

In the box model used, the nutrient and carbon fluxes are obtained by multiplying the flow rates (Table 2 ) by the concentrations (Fig. 4). In this way, the ingoing, outgoing, ascending and descending fluxes of nutrient salts and organic carbon for the box are calculated. Results are collated in Table 3. These fluxes are completed by the contribution due to freshwater, derived from the flow rates (Prego \& Fraga in press) entering the ria by run off, the River Oitaven, and residual waters from the city of Vigo, together with the corresponding concentrations (Prego 1989). 
Fig. 2, Ria of Vigo, NW Spain, and stations sampled on 4 and 21 September and 3 October. In order to apply the box model shown at lower right, the zone is considered in the upper ria to $\mathrm{Stn} 3(56.48$ $\mathrm{km}^{2}$ and $\left.0.678 \mathrm{~km}^{3}\right) . \mathrm{F}_{\mathrm{e}}$ and $\mathrm{F}_{\mathrm{s}}$ : incoming and outgoing fluxes; $F_{d}$ and $F_{a}$ : descending and ascending fluxes; $\mathrm{F}_{\mathrm{r}}$ : flux due to freshwater

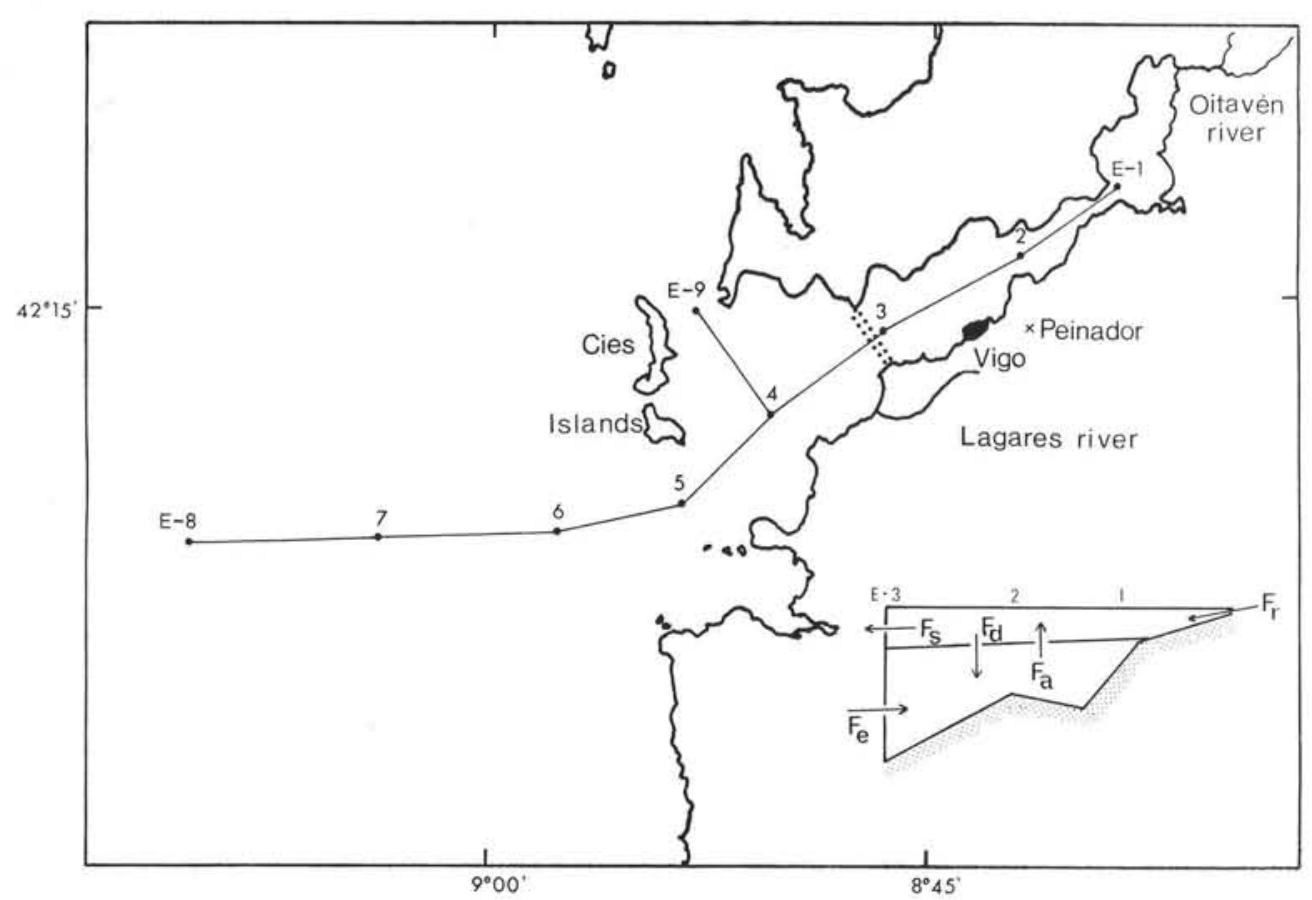

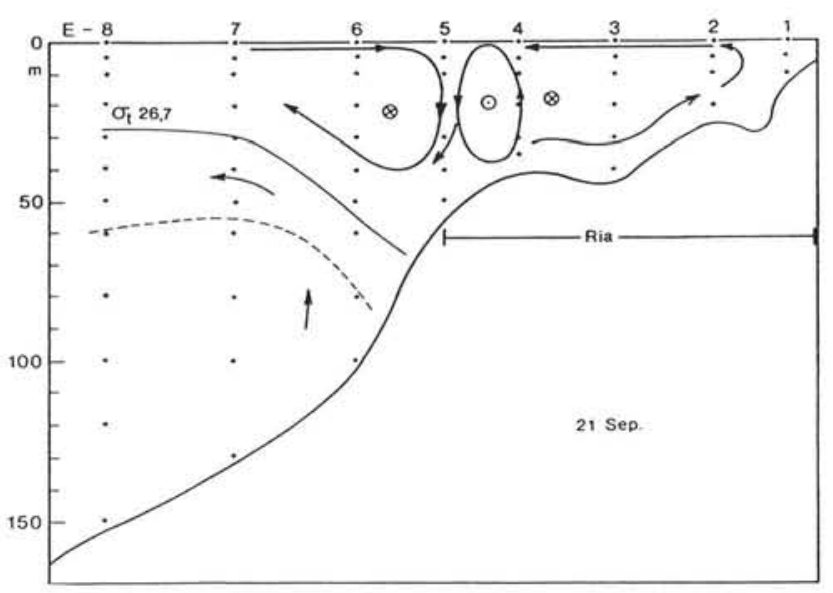

Fig. 3. Scheme of the vertical circulation which occurred abnormally on 21 September (Fraga \& Prego 1989). Numbers correspond to stations shown in Fig. 2

\section{Budgets of nutrient salts and carbon}

The balances, A and B respectively for the upper and lower layers, in nutrient salts and carbon are obtained from the fluxes in the 2 layers (Fig. 2) thus:

$$
\begin{aligned}
& \text { upper layer: } A=F_{a}-F_{d}-F_{s}+F_{r} \\
& \text { lower layer: } B=-F_{a}+F_{d}+F_{e}
\end{aligned}
$$

where $F_{e}, F_{s}, F_{a}$ and $F_{d}$ are, respectively, the incoming, outgoing, ascending and descending nutrient and carbon fluxes in the box, and $F_{r}$ is the contribution from freshwater (Table 3).

The results for $\mathrm{A}$ and $\mathrm{B}$ are given in Table 4. The balance in each layer is non-zero since there are biogeochemical processes which remove or contribute substances independently of the physical processes. The principal source of error is due to the calculation of

Table 1. Depth at Stns 1, 2 and 3 (Fig. 2) where the velocity of the residual current is zero, and at Stn 3 where the penetration of

\begin{tabular}{|c|c|c|c|c|c|c|}
\hline \multirow[t]{2}{*}{ Date } & \multicolumn{4}{|c|}{ Depth (m) } & \multicolumn{2}{|c|}{ Volume $\left(10^{6} \mathrm{~m}^{3}\right)$} \\
\hline & Stn 1 & Stn 2 & Stn 3 & $1 \%$ & Upper layer & Lower layer \\
\hline $4 \mathrm{Sep}$ & 5.7 & 11.6 & 11.5 & 9.5 & 391 & 287 \\
\hline 21 Sep & 5.2 & 7.8 & 12.7 & 12.0 & 352 & 326 \\
\hline 3 Oct & 4.4 & 7.6 & 11.3 & $11^{a}$ & 333 & 345 \\
\hline
\end{tabular}
light is $1 \%$. Volumes of the 2 layers on the 3 dates studied. The total volume of the box is $678 \times 10^{6} \mathrm{~m}^{3}$ 


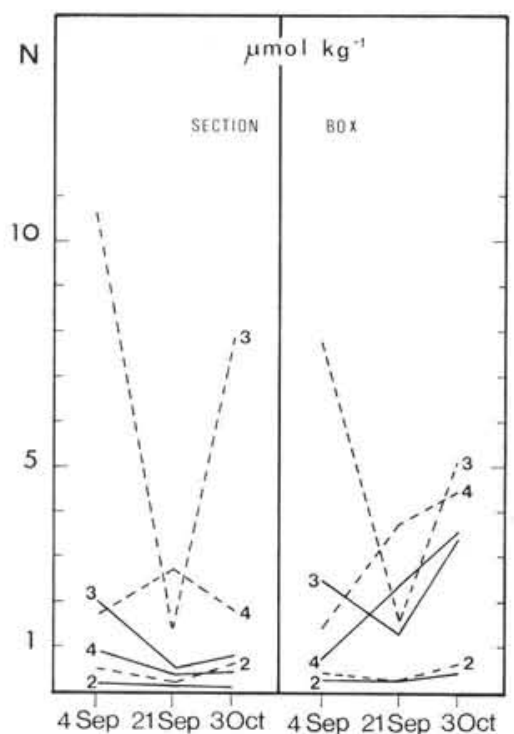

Table 2. Flows $\left(10^{3} \mathrm{~kg} \mathrm{~s}^{-1}\right)$ contributing to the residual circulation in the Ria of Vigo (data from Prego \& Fraga in press). The outgoing flux, $F_{S}$, is the incoming flux, $F_{e}$, plus the flux of freshwater, $\mathrm{F}_{\mathrm{r}}$. The ascending flux, $\mathrm{F}_{\mathrm{a}}$ is the incoming flux, $\mathrm{F}_{\mathrm{e}}$, plus the mixing, $F_{d}$; see Fig 2 . Time, $t_{r}$ in days, needed to totally renew the water in the upper layer is also indicated

\begin{tabular}{|rrrcrrr|}
\hline Date & $\mathrm{F}_{\mathrm{r}}$ & $\mathrm{F}_{\mathrm{e}}$ & $\mathrm{F}_{\mathrm{s}}$ & $\mathrm{F}_{\mathrm{d}}$ & $\mathrm{F}_{\mathrm{a}}$ & \multicolumn{1}{c}{$\mathrm{t}_{\mathrm{r}}$} \\
\hline 4 Sep & 1.5 & 484 & 486 & 1012 & 1496 & 10.5 \\
21 Sep & 12.8 & 862 & 875 & 651 & 1513 & 5.0 \\
3 Oct & 3.3 & 246 & 249 & 359 & 605 & 15.0 \\
\hline
\end{tabular}

the flow rates of fresh water emptying into the ria. This means that for each date the results may have an overall variation of ca $10 \%$ for the fluxes and the balances obtained.

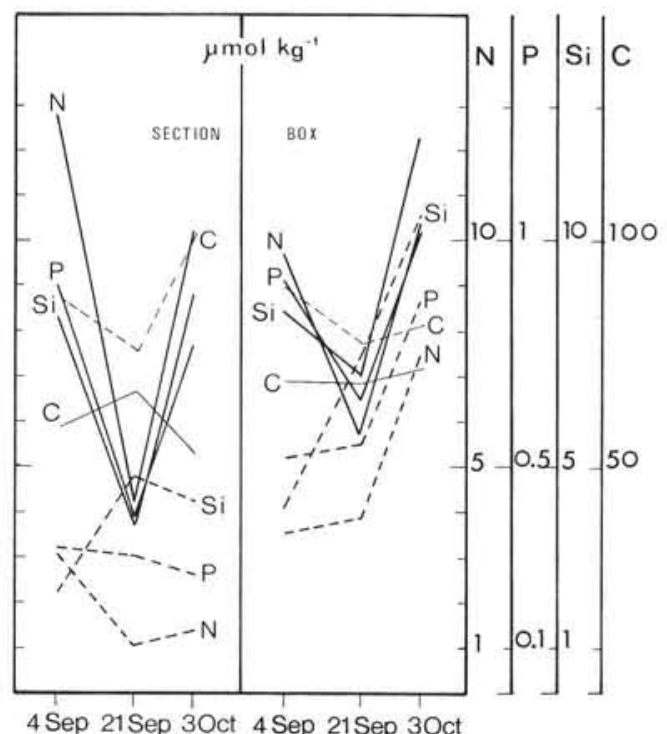

Fig. 4. Mean concentrations of nitrite (2), nitrate (3) and ammonium (4), inorganic nitrogen $(\mathrm{N})$, phosphate $(\mathrm{P})$, silicate $(\mathrm{Si})$ and organic carbon $(\mathrm{C})$ in the box considered in the ria of Vigo and the dividing section (i.e. E-3 in Fig. 2) for the 3 study dates (4 and 21 September; 3 October). Continuous lines: upper layer and subsection of the box: dashed lines: lower layer and subsection

Table 3. Fluxes ( $\mathrm{mol} \mathrm{s}^{-1}$ box $^{-1}$ ) of nutrient salts and carbon in the box in the Ria of Vigo (Fig. 2). $\mathrm{F}_{\mathrm{r}}$ : flux due to freshwater; $\mathrm{F}_{\mathrm{e}}$ and $\mathrm{F}_{\mathrm{s}}$ : incoming and outgoing fluxes; $\mathrm{F}_{\mathrm{a}}$ and $\mathrm{F}_{\mathrm{d}}$ : ascending and descending fluxes. Si: silicate; $\mathrm{N}_{\mathrm{in}}$ and $\mathrm{C}_{\mathrm{in}}$ : inorganic nitrogen and carbon; $\mathrm{C}_{\text {or }}$ : organic carbon

\begin{tabular}{|c|c|c|c|c|c|c|c|c|c|}
\hline Date & Flux & $\mathrm{NO}_{3}^{-}$ & $\mathrm{NO}_{2}^{-}$ & $\mathrm{NH}_{4}{ }^{+}$ & $\mathrm{N}_{\text {in }}$ & $\mathrm{HPO}_{4}{ }^{2-}$ & $\mathrm{Si}$ & $\mathrm{C}_{\text {in }}$ & $\mathrm{C}_{\text {or }}$ \\
\hline \multirow[t]{5}{*}{4 Sep } & $\mathrm{F}_{\mathrm{r}}$ & 0.04 & 0.00 & 0.27 & 0.31 & 0.041 & 0.23 & 0 & 3 \\
\hline & $\mathrm{F}_{\mathrm{s}}$ & 0.97 & 0.10 & 0.44 & 1.51 & 0.162 & 1.12 & 1017 & 43 \\
\hline & $\mathrm{F}_{\mathrm{e}}$ & 5.20 & 0.24 & 0.83 & 6.27 & 0.442 & 4.06 & 1044 & 29 \\
\hline & $\mathrm{F}_{\mathrm{a}}$ & 11.61 & 0.75 & 2.67 & 15.03 & 1.373 & 12.71 & 3165 & 103 \\
\hline & $\mathrm{F}_{\mathrm{d}}$ & 2.57 & 0.25 & 0.82 & 3.64 & 0.535 & 4.23 & 2088 & 91 \\
\hline \multirow[t]{5}{*}{21 Sep } & $\mathrm{F}_{\mathrm{r}}$ & 0.14 & 0.01 & 0.29 & 0.44 & 0.042 & 1.53 & 0 & 4 \\
\hline & $\mathrm{F}_{\mathrm{s}}$ & 0.46 & 0.14 & 0.34 & 0.94 & 0.268 & 4.26 & 1799 & 67 \\
\hline & $\mathrm{F}_{\mathrm{e}}$ & 1.22 & 0.15 & 2.30 & 3.67 & 0.333 & 3.24 & 1819 & 58 \\
\hline & $\mathrm{F}_{\mathrm{a}}$ & 2.29 & 0.42 & 5.81 & 8.52 & 0.986 & 10.74 & 3182 & 105 \\
\hline & $\mathrm{F}_{\mathrm{d}}$ & 0.82 & 0.16 & 1.59 & 2.57 & 0.366 & 4.85 & 1340 & 51 \\
\hline \multirow[t]{5}{*}{3 Oct } & $\mathrm{F}_{\mathrm{r}}$ & 0.05 & 0.00 & 0.28 & 0.33 & 0.064 & 0.23 & 0 & 3 \\
\hline & $\mathrm{F}_{\mathrm{s}}$ & 0.19 & 0.03 & 0.11 & 0.33 & 0.067 & 1.08 & 520 & 25 \\
\hline & $\mathrm{F}_{\mathrm{e}}$ & 1.93 & 0.17 & 0.44 & 2.54 & 0.192 & 2.20 & 539 & 13 \\
\hline & $\mathrm{F}_{\mathrm{a}}$ & 3.11 & 0.43 & 2.75 & 6.29 & 0.631 & 7.50 & 1308 & 44 \\
\hline & $\mathrm{F}_{\mathrm{d}}$ & 1.23 & 0.18 & 1.30 & 2.71 & 0.311 & 3.81 & 754 & 30 \\
\hline
\end{tabular}


Table 4. Balance $\left(\mathrm{mol} \mathrm{s}^{-1}\right.$ box $\left.^{-1}\right)$ of nutrient salts and carbon fluxes in the box in the Ria of Vigo (Fig. 2). A positive value of inorganic nitrogen in the upper layer, A, is due to its consumption in photosynthesis, and a negative value in the lower layer, B, is due to its appearance by remineralisation. Phosphate and inorganic carbon need the corrections of Appendices 1 \& 2 . Si: silicate; $\mathrm{N}_{\text {in }}$ : inorganic nitrogen; $\mathrm{C}_{\mathrm{in}}$ : inorganic carbon; $\mathrm{C}_{\mathrm{or}}$ : organic carbon

\begin{tabular}{|c|c|c|c|c|c|c|c|c|c|}
\hline Date & Layer & $\mathrm{NO}_{3}^{-}$ & $\mathrm{NO}_{2}^{-}$ & $\mathrm{NH}_{4}{ }^{+}$ & $\mathrm{N}_{\text {in }}$ & $\mathrm{HPO}_{4}{ }^{2-}$ & $\mathrm{Si}$ & $\mathrm{C}_{\mathrm{in}}$ & $\mathrm{C}_{\mathrm{or}}$ \\
\hline 4 Sep & $\begin{array}{l}\mathrm{A} \\
\mathrm{B}\end{array}$ & $\begin{array}{l}+8.11 \\
-3.84\end{array}$ & $\begin{array}{l}+0.40 \\
-0.26\end{array}$ & $\begin{array}{l}+1.68 \\
-1.02\end{array}$ & $\begin{array}{r}+10.19 \\
-5.12\end{array}$ & $\begin{array}{l}+0.72 \\
-0.40\end{array}$ & $\begin{array}{l}+7.59 \\
-4.42\end{array}$ & $\begin{array}{l}+58 \\
-30\end{array}$ & $\begin{array}{l}-28.2 \\
+16.9\end{array}$ \\
\hline 21 Sep & $\begin{array}{l}\text { A } \\
\text { B }\end{array}$ & $\begin{array}{l}+1.15 \\
-0.25\end{array}$ & $\begin{array}{l}+0.13 \\
-0.11\end{array}$ & $\begin{array}{l}+4.17 \\
-1.92\end{array}$ & $\begin{array}{l}+5.45 \\
-2.28\end{array}$ & $\begin{array}{l}+0.39 \\
-0.29\end{array}$ & $\begin{array}{l}+3.16 \\
-2.65\end{array}$ & $\begin{array}{l}+43 \\
-23\end{array}$ & $\begin{array}{r}-9.8 \\
+\quad 4.0\end{array}$ \\
\hline $3 \mathrm{Oct}$ & $\begin{array}{l}\mathrm{A} \\
\mathrm{B}\end{array}$ & $\begin{array}{l}+1.74 \\
-0.05\end{array}$ & $\begin{array}{l}+0.22 \\
-0.08\end{array}$ & $\begin{array}{l}+1.63 \\
-1.01\end{array}$ & $\begin{array}{l}+3.58 \\
-1.04\end{array}$ & $\begin{array}{l}+0.32 \\
-0.13\end{array}$ & $\begin{array}{l}+2.84 \\
-1.49\end{array}$ & $\begin{array}{l}+34 \\
-15\end{array}$ & $\begin{array}{l}-8.4 \\
-\quad 0.8\end{array}$ \\
\hline
\end{tabular}

the effects of flocculation (used here as a general term denoting change from the dissolved to the solid phase) and redissolution, according to the processes referred to by Aston (1980). These processes are included in the values A and B for phosphate balance shown in Table 4 . The necessary correction factors are derived in Appendix 1, and the corrected values of phosphate consumed in photosynthesis or appearing through remineralisation presented in Table 5.

The balance of inorganic carbon (A and B in Table 4) are affected, in a similar way to phosphate, by processes such as the dissolution or precipitation of carbonates as well as by the interchange of carbon dioxide with the atmosphere. The correction needed to calculate the inorganic carbon used in photosynthesis or remineralisation (Table 5) is derived in Appendix 2, where the input and sedimentation of particulate organic carbon in the lower layer is also calculated (Fig. 11).

\section{Agreement of photosynthesis and remineralisation results}

The values for inorganic carbon, nitrogen and phosphorus consumed by photosynthesis or regenerated by remineralisation in the ria (Table 5) are related in accordance with the following stoichometric equation for photosynthesis-remineralisation:

$$
\begin{aligned}
& 129 \mathrm{HCO}_{3}^{-}+17 \mathrm{NO}_{3}^{-}+\mathrm{HPO}_{4}^{2-}+126 \mathrm{H}_{2} \mathrm{O} \rightleftharpoons \\
& \left(\mathrm{C}_{129} \mathrm{H}_{234} \mathrm{~N}_{17} \mathrm{O}_{70} \mathrm{P}\right)+175 \mathrm{O}_{2}+148 \mathrm{OH}^{-}
\end{aligned}
$$

This expression is obtained from the ratio of $\mathrm{C}: \mathrm{H}: \mathrm{N}: \mathrm{O}: \mathrm{P}$ of 129:234:17:70:1 calculated by Rios \& Fraga (1987) for the phytoplankton of the Ria of Vigo and the forms in which the nutrient salts and inorganic carbon are found in seawater. Thus the values for photosynthesis and remineralization obtained in Table 5 can be compared. The balances of inorganic nitrogen and phosphate are expressed in $\mathrm{mol} \mathrm{C} \mathrm{s}^{-1}$ box $^{-1}$ by the stoichiometric relations of Eq. (3) in Table 6. There is agreement

Table 5. Values obtained, after balance (Table 4) and corrections of Appendices 1 \& 2 (Tables 7 \& 8), for photosynthesis, fall,

\begin{tabular}{|c|c|c|c|c|}
\hline Date & Process & $\begin{array}{c}\text { Carbon } \\
\left(\mathrm{mol} \mathrm{C} \mathrm{s}^{-1} \mathrm{box}^{-1}\right)\end{array}$ & $\begin{array}{c}\text { Nitrogen } \\
\left(\mathrm{mol} \mathrm{N} \mathrm{s}^{-1} \text { box }^{-1}\right)\end{array}$ & $\begin{array}{c}\text { Phosphorus } \\
\left(\mathrm{mol} \mathrm{P} \mathrm{s}^{-1} \mathrm{box}^{-1}\right)\end{array}$ \\
\hline 4 Sep & $\begin{array}{l}\text { Photosynthesis } \\
\text { Fall } \\
\text { Remineralisation } \\
\text { Sedimentation }\end{array}$ & $\begin{array}{l}77.6 \\
49.4 \\
36.3 \\
30.0\end{array}$ & $\begin{array}{c}10.19 \\
- \\
5.12 \\
-\end{array}$ & $\begin{array}{c}0.58 \\
- \\
0.28 \\
-\end{array}$ \\
\hline 21 Sep & $\begin{array}{l}\text { Photosynthesis } \\
\text { Fall } \\
\text { Remineralisation } \\
\text { Sedimentation }\end{array}$ & $\begin{array}{r}41.2 \\
31.4 \\
33.0 \\
2.4\end{array}$ & $\begin{array}{c}5.45 \\
- \\
2.28 \\
-\end{array}$ & $\begin{array}{c}0.32 \\
- \\
0.20 \\
-\end{array}$ \\
\hline 3 Oct & $\begin{array}{l}\text { Photosynthesis } \\
\text { Fall } \\
\text { Remineralisation } \\
\text { Sedimentation }\end{array}$ & $\begin{array}{r}28.7 \\
20.3 \\
12.9 \\
6.6\end{array}$ & $\begin{array}{c}3.58 \\
- \\
1.04 \\
-\end{array}$ & $\begin{array}{c}0.22 \\
- \\
0.07 \\
-\end{array}$ \\
\hline
\end{tabular}
remineralisation and sedimentation of carbon, nitrogen and phosphorus in the box 
Table 6. Values obtained ( $\mathrm{mol} \mathrm{C} \mathrm{s}^{-1} \mathrm{box}^{-1}$ ) for comparing the results of the photosynthesis and the remineralisation of nitrogen and phosphorus (Table 5) with that of carbon, as taken from the quotient of the stoichiometric coefficients bicarbonate:nitrate (7.59) and bicarbonate:phosphate (129) from Eq. (3). For the box considered there is the relation: $1 \mathrm{~mol} \mathrm{C}$ $\mathrm{s}^{-1}$ box $^{-1}=18.4 \mathrm{mg} \mathrm{C} \mathrm{m}^{-2} \mathrm{~d}^{-1}$

\begin{tabular}{|rrrrrrr|}
\hline Date & \multicolumn{3}{c}{ Photosynthesis } & \multicolumn{3}{c|}{ Remineralisation } \\
& $\mathrm{C}$ & $\mathrm{N} \times 7.59$ & $\mathrm{P} \times 129$ & $\mathrm{C}$ & $\mathrm{N} \times 7.59$ & $\mathrm{P} \times 129$ \\
\hline 4 Sep & 78 & 77 & 75 & 36 & 39 & 36 \\
21 Sep & 41 & 41 & 41 & 33 & 17 & 26 \\
3 Oct & 29 & 27 & 28 & 13 & 8 & 9 \\
\hline
\end{tabular}

between the 3 different methods described above for the values of photosynthesis and remineralization. The discrepancy in the nitrogen remineralization values for 21 September will be commented upon below.

\section{DISCUSSION}

Before the red tide was detected, hydrographic conditions on 4 September were typical for the summer (Figs. 5 to 8). The northerly winds, which began in the last week of August, caused an upwelling which enriched the nutrient salts in the ria: the inflowing water transported $6.3 \mathrm{~mol} \mathrm{~s}^{-1}$ of inorganic nitrogen, of which $83 \%$ was nitrate; $0.44 \mathrm{~mol} \mathrm{~s}^{-1}$ of phosphate; and $4.1 \mathrm{~mol} \mathrm{~s}^{-1}$ of silicate (Table 3). The lower layer of the box was thus rich in nutrient salts (Fig. 4). The chlorophyll concentration was high (Fig. 8) as was photosynthesis: $78 \mathrm{~mol} \mathrm{C} \mathrm{s}^{-1}$ (Table 6), 1.5 times greater than the summer mean for this zone of the ria (Vives \& Fraga 1961). There was an abundance of diatoms, $75 \%$ of phytoplankton cells (Figueiras \& Fraga 1990), which consumed $60 \%$ of the silicate arriving in the upper layer: $7.6 \mathrm{~mol} \mathrm{~s}^{-1}$ (Table 4).

The depth of penetration of $1 \%$ light, obtained using a Secchi disc, is given in Table 1. This is shallower than the level of zero velocity, and is the reason why the outgoing current is not exhausted in nutrients: $1.5 \mathrm{~mol}$ $\mathrm{N} \mathrm{s}^{-1}$ (with $64 \%$ as nitrate), $0.16 \mathrm{~mol} \mathrm{P} \mathrm{s}^{-1}$ and $1.1 \mathrm{~mol}$ $\mathrm{Si} \mathrm{s}^{-1}$ flowed back to the ocean. The balance of organic carbon in the box is $14 \mathrm{~mol} \mathrm{C} \mathrm{s}^{-1}$ in favour of the outgoing flux (Table 3).

On 21 September, when the winds had changed to southerly (Fig. 1), an occlusion was produced in the ria at Stns 4 \& 5 (Fig. 5). Circulation took place in a semiclosed circuit (Fig. 3) which affected the distribution of the nutrient salts (Figs. $6 \&$ 7) and chlorophyll $a$ (Fig. 8). The recirculation led to the concentrations of substances in the incoming and outgoing currents resembling each other, as shown by the closeness of the continuous and discontinuous lines in Fig. 4.
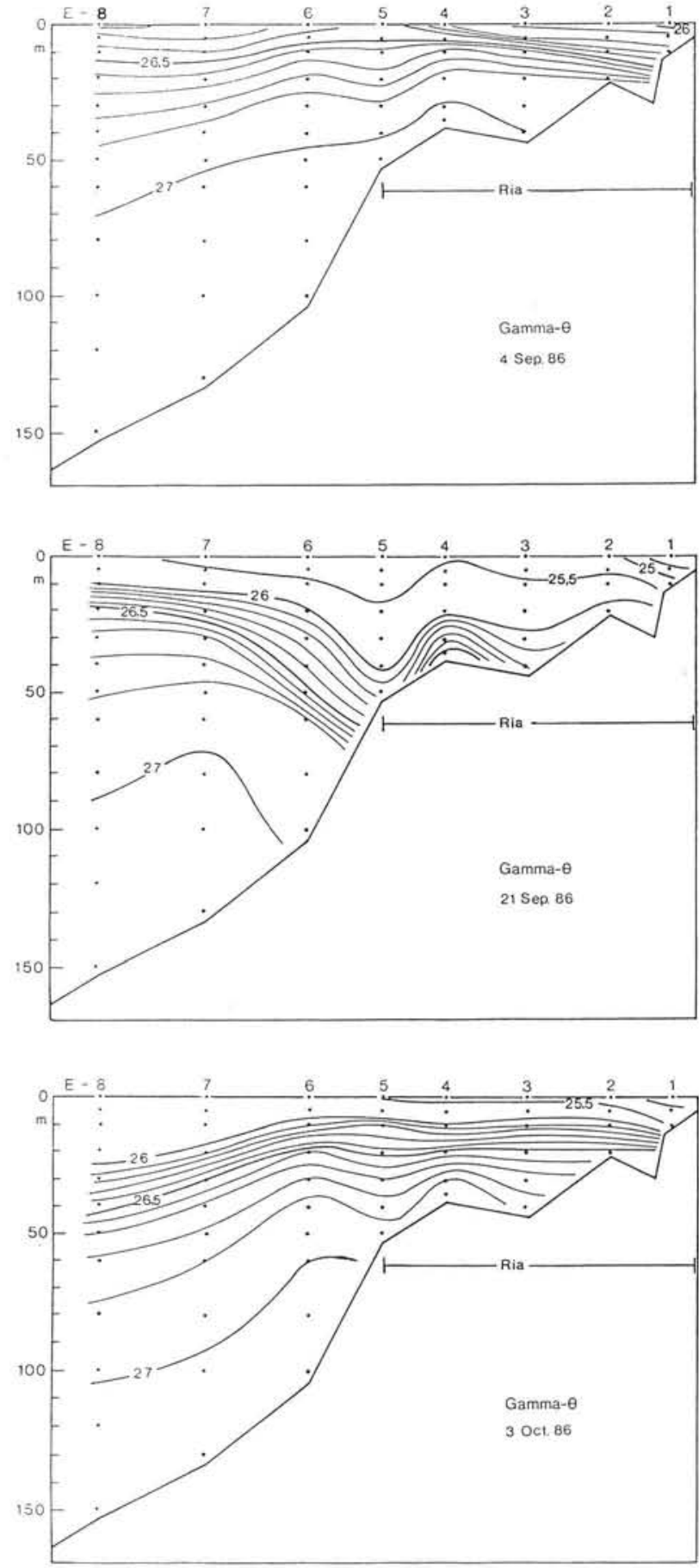

Fig. 5. Vertical distribution of density in the Ria of Vigo and its offshore waters (Prego et al. 1988). Gamma- $\theta$ is density minus $1000 \mathrm{~kg} \mathrm{~m}^{-3}$, and the unit is $\mathrm{kg} \mathrm{m}^{-3}$

The homogenization of the water in the ria was not due to greater mixing but rather to recirculation. This will have greater importance for the increase in water temperature than the inflow of warm water from the exterior, as indicated by Fraga et al. (1988). The mean 

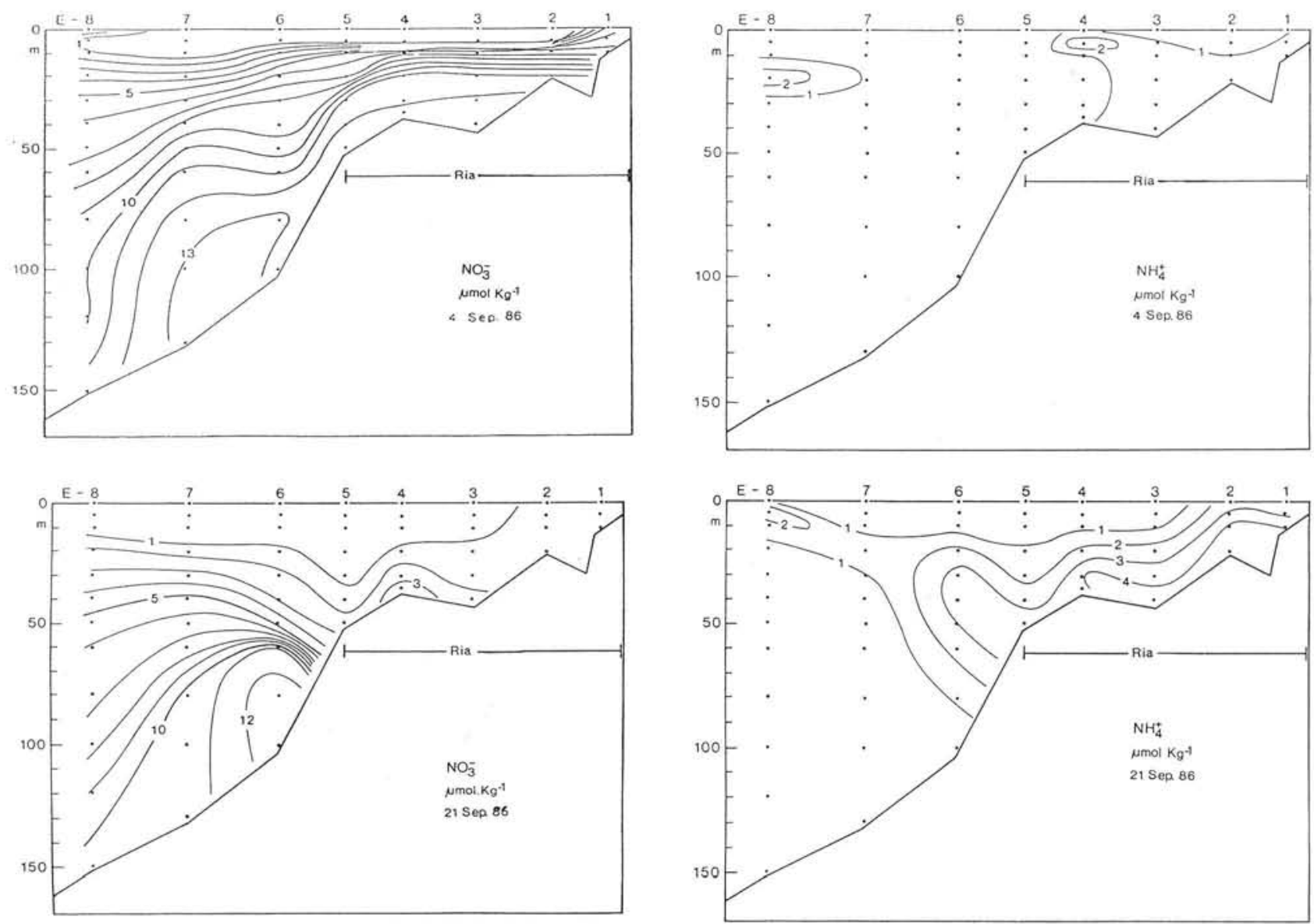

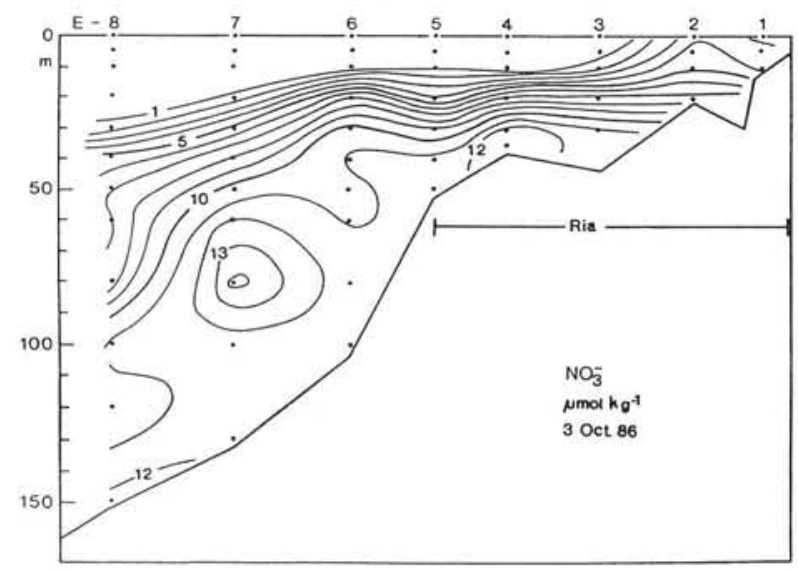

Fig. 6. Vertical distribution of nitrate in the Ria of Vigo and its offshore waters (Prego et al. 1988)

temperature was $16.7^{\circ} \mathrm{C}$ in the upper layer and $16.1^{\circ} \mathrm{C}$ in the lower layer (calculated from the data of Prego et al. 1988). Tangen (1977) pointed out the importance of an increase in seawater temperature in the development of red tides in north European waters, and Chang \& Carpenter (1985) found statistically significant correlations between the logarithm of cell densities and

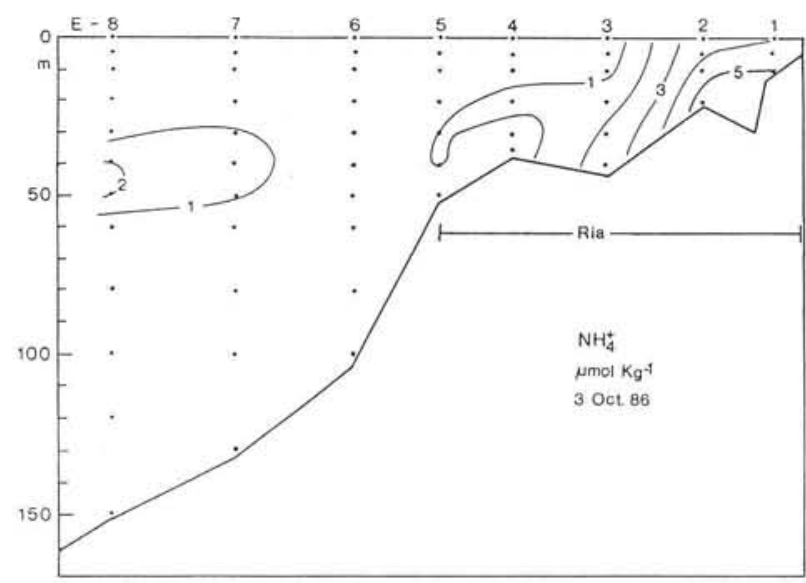

Fig. 7. Vertical distribution of ammonium in the Ria of Vigo and its offshore waters (Prego et al. 1988)

water temperature during a bloom of Gyrodinium aureolum in the Carmans River estuary (Long Island, USA). This phenomenon may not have an influence on the development of red tides, but be simply one of the consequences of hydrographic conditions. More research would be needed on this subject and also on the possible role of resuspension of cyst due to recircu- 

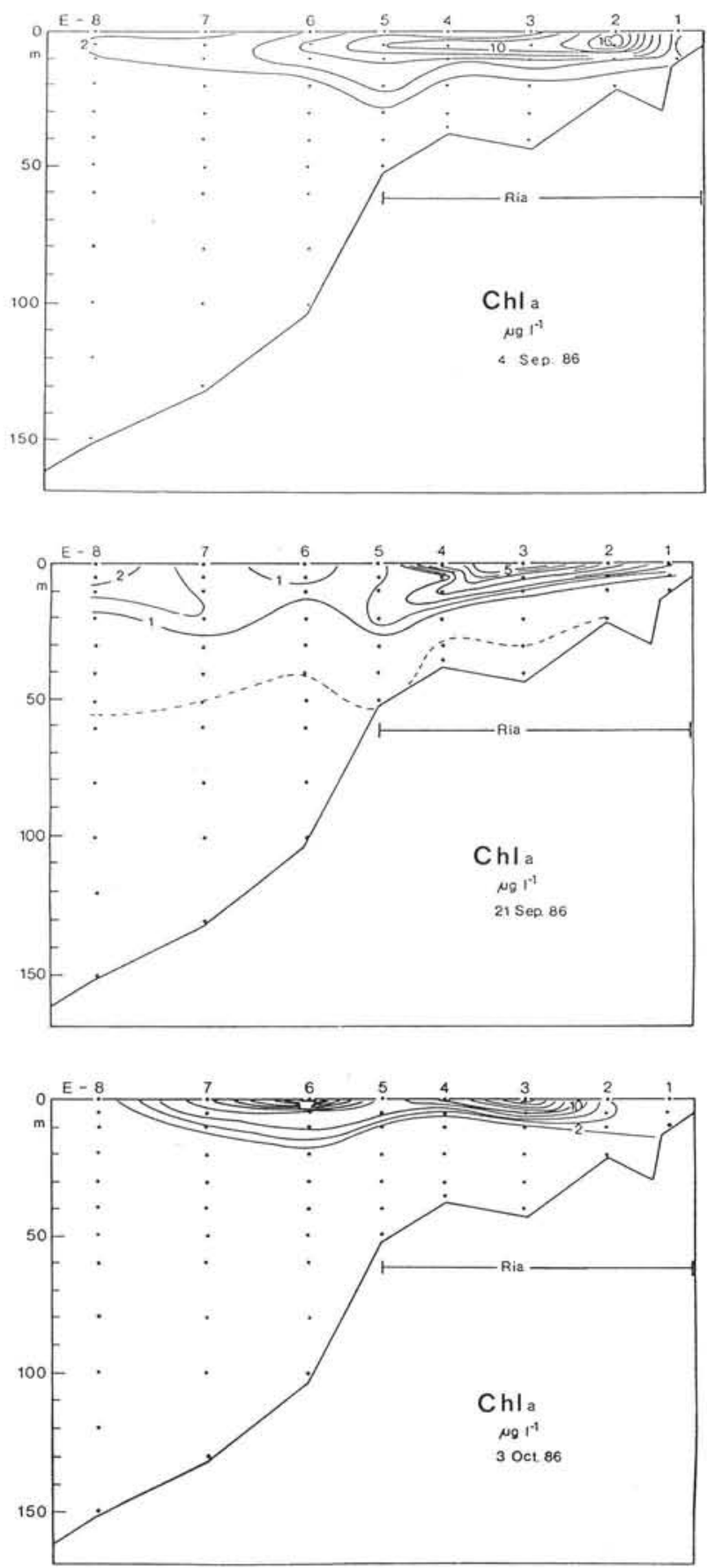

Fig. 8. Vertical distribution of chlorophyll $a$ in the Ria of Vigo and its offshore waters (Prego et al. 1988)

lation: the residual incoming flux is nearly double that measured during the preceding sampling $\left(\mathrm{F}_{\mathrm{e}}\right.$ in Table 2 ). Probably the more important effect of currents on the sediment would be in the frontal zone (between Stns $4 \& 5$; Figs. $2 \& 3$ ) where, near the seabed, the temperature increased from 12.5 to $16^{\circ} \mathrm{C}$ between 4 and 21 September.
The retention brought about the arrival of recycled nutrients in the incoming seawater. The $3.7 \mathrm{~mol} \mathrm{~N} \mathrm{~s}^{-1}$ entering (approximately half of that on 4 September) was now poor in nitrates (33\%; Table 3$)$. Remineralization was very high (Fig. 7), representing three-quarters of the amount photosynthesized (Table 5). Sedimentation, on the basis of carbon data (Table 5), was almost zero, i.e. there was strong decomposition of organic matter as a consequence of the water retention.

Under these condictions, photosynthesis was maintained through remineralized nutrients $\left(4.2 \mathrm{~mol} \mathrm{~s}^{-1}\right.$ of $\mathrm{NH}_{4}^{+}$as opposed to $8.1 \mathrm{~mol} \mathrm{~s}^{-1}$ of $\mathrm{NO}_{3}{ }^{-}$on 4 September; Table 4), i.e. $80 \%$ of the inorganic nitrogen used in photosynthesis on 4 September corresponded to nitrate, while on 21 September $77 \%$ corresponded to ammonium. Yamochi \& Abe (1984), by comparing changes in their concentrations, noted that the uptake rate for ammonium was much higher than for other forms of dissolved inorganic nitrogen. On 21 September, the consumption of silicate decreased 2.5 fold (Table 4) to less than half of that of 4 September, despite its influx to the upper layer being almost equal (10.7 $\mathrm{mol} \mathrm{Si} \mathrm{s}^{-1}$ in the ascending flux and $1.5 \mathrm{~mol} \mathrm{Si} \mathrm{s}^{-1}$ in the freshwater; Table 3 ). Of this silicate, only $26 \%$ was used and, on this date, export $\left(4.3 \mathrm{~mol} \mathrm{Si} \mathrm{s}^{-1}\right)$ was greater than import $\left(3.2 \mathrm{~mol} \mathrm{Si} \mathrm{s}^{-1}\right)$ coinciding with a large reduction in the concentration of diatoms in the ria (Figueiras \& Fraga 1990). Organic carbon maintained its concentration (Fig. 4) despite the halving in production; it may have an important role as a source of organic substances for phytoplankton and bacteria or also in the stabilization of metals in the seawater, due to its capacity for complexing (Siegel 1971, Huntsman \& Sunda 1980).

Gymnodinium catenatum, hardly present on 4 September (Fig. 9), increased its concentration in the box to $10^{4}$ cell $\mathrm{dm}^{-3}$ and probably grew from the inoculum of 4 September (Figueiras 1989). This was favoured not only by chemical causes such as ammonium and organic carbon availability, but also by physical causes such as the rapid circulation $\left(862 \times 10^{3} \mathrm{~kg} \mathrm{~s}^{-1}\right.$, almost double that of the 4 September; Table 2), and low mixing $\left(\mathrm{F}_{\mathrm{d}}\right.$ in Table 2$)$ of the water in the box, half that of the previous date. The rains (in September 1986, $232 \mathrm{~mm}$ of rainfall were recorded in Peinador, which is double the average for the month) which accompanied the southerly winds (Fig. 1) produced inputs of freshwater to the ria (Fig. 1) which increased the stability of the water as shown by the isopycnals of 21 September (Fig. 5). These hydrographic conditions favoured the growth of a population of mobile flagellates much more than diatoms (Eppley et al. 1978). Diatoms lose many cells by sedimentation, but dinoflagellates, due to movement of flagella, are able to keep near the surface (Margalef et al. 1979). The low turbulent diffusion and 

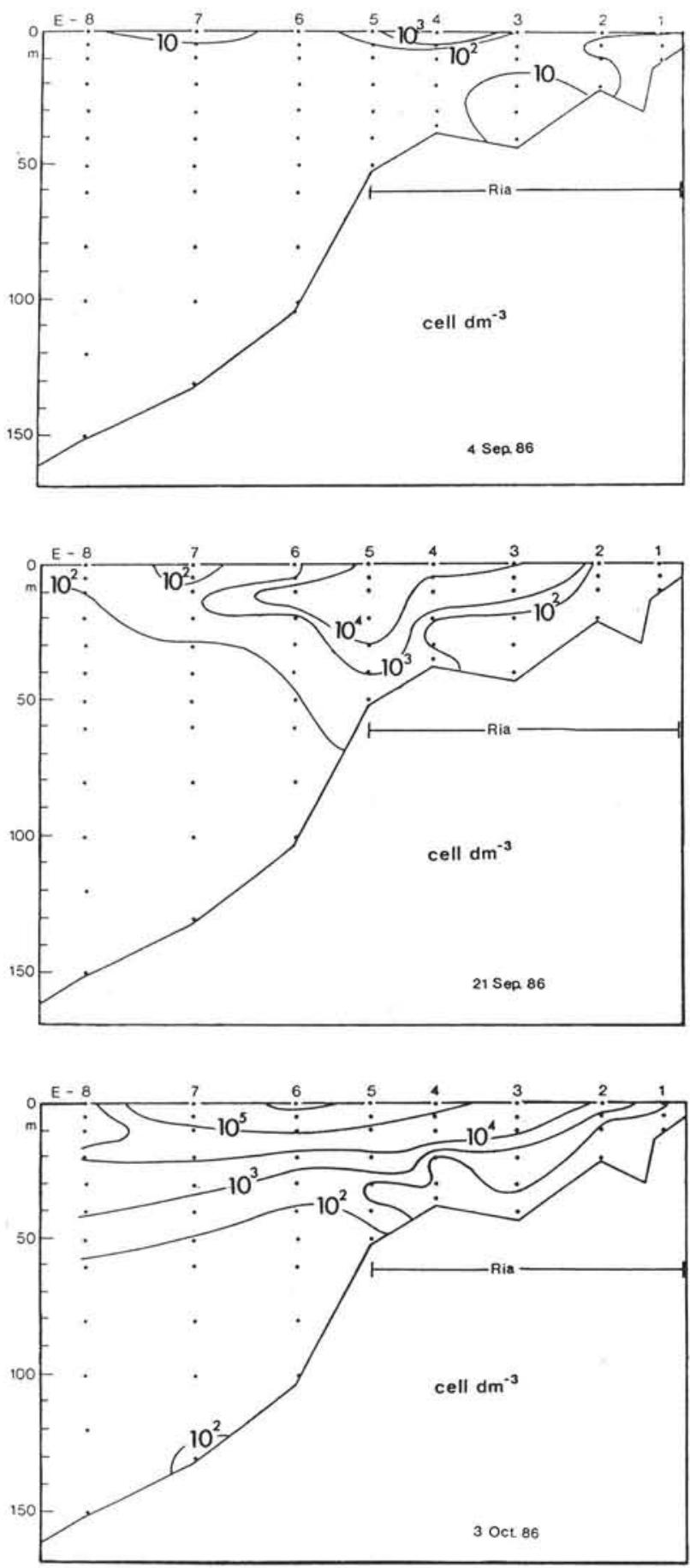

Fig. 9. Vertical distribution of Gymnodinium catenatum in the Ria of Vigo and its offshore waters (Figueiras \& Fraga 1990)

high concentration of nutrients gave rise to the formation of a red tide. Production fell from $1410 \mathrm{mg} \mathrm{C} \mathrm{m}^{-2}$ $\mathrm{d}^{-1}$ on 4 September to $755 \mathrm{mg} \mathrm{C} \mathrm{m}^{-2} \mathrm{~d}^{-1}$ on 21 September (Table 6). As Margalef (1956) indicated, there occurs a concentration of phytoplankton rather than a maintenance of the total mass. Consequently, the Gym- nodinium catenatum produced in the interior of the ria will accumulate in the zone of convergence (Stns 4 \& 5; Fig. 9), where the increase in concentration will be higher than the losses (Slobodkin 1953). The sampling station for the data of Fig. 1 was situated near Stn 5 (Fig. 2), where an increase in Gymnodinium catenatum was observed on 21 September.

The question posed in the 'Introduction', in relation to the sources of nutrient salts in this red tide, can now be answered. The contributions of nutrient salts will come mainly from the remineralization of organic matter and the amounts contributed by the freshwater will not have an appreciable effect. There are no important residues of anthropogenic origin entering the ria, as happens along the coasts of Scandinavia (Smayda 1990). In this ria the inputs of freshwater are only $5 \%$ of the inorganic nitrogen and phosphorus and $12 \%$ of the silicate contained in the flux rising to the upper layer (Table 3).

Another factor which may play an important role is vertical migration of the dinoflagellates (Yamochi \& Abe 1984, Cohen 1985). This vertical movement is ca $10 \mathrm{~m} \mathrm{~d}^{-1}$ (Cullen 1985). It is of significance in the ria (Fraga \& Prego 1989, Figueiras \& Fraga 1990) since it allows Gymnodinium catenatum to photosynthesise carbohydrates in the upper layer, and then to descend to the lower layer where it can assimilate nitrates, as in the case of other dinoflagellates (Eppley \& Harrison 1975, MacIsaac 1978, Cullen \& Horringan 1981, Dortch \& Maske 1982), using the chemical energy accumulated. This causes a discrepancy between the remineralisation values for $\mathrm{C}, \mathrm{N}$ and $\mathrm{P}$, calculated on 21 September (Table 6). The migration will, in the deep layer, produce a greater remineralization of organic carbon and a lower value for nitrogen remineralisation. Although more research is needed, it is possible to estimate the synthesis of organic matter in the lower layer. The discrepancy of $16 \mathrm{~mol} \mathrm{C} \mathrm{s}^{-1}$ (Table 6) between $\mathrm{C}$ and $\mathrm{N}$ will be redistributed, but $\mathrm{P}$ remineralisation is not affected by this process: $9 \mathrm{~mol} \mathrm{C}$ $\mathrm{s}^{-1}$ in synthesized matter and $7 \mathrm{~mol} \mathrm{C} \mathrm{s}^{-1}$ as an energy source. $17 \%$ of the photosynthesized material $(21 \%$ of the remineralised carbon) is used as an energy source for the synthesis of nitrogenous organic matter. The $9 \mathrm{~mol} \mathrm{C} \mathrm{s}{ }^{-1}$ correspond, according to the above mentioned ratio, to $1.2 \mathrm{~mol} \mathrm{~N} \mathrm{~s}^{-1}$, which is $22 \%$ of the total synthesized in the box. Dissolved inorganic nitrogen will be therefore, as Harrison (1973), Lindahl (1983) and Holligan et al. (1984) have indicated, one of the major factors that control the occurrence of many dinoflagellate blooms.

The retention of water in the ria disappeared by 3 October. The isopycnal of $26.7 \mathrm{~kg} \mathrm{~m}^{-3}$ (Fig. 5) was now found in the ria. The residual fluxes were about $250 \times 10^{3} \mathrm{~kg} \mathrm{~s}^{-1}$ (Table 2), and a renewal of the water 
in the box took place. The outgoing flux was now rich in ammonium (about $0.8 \mu \mathrm{mol} \mathrm{kg}{ }^{-1}$ more than on 21 September; Fig. 4) but the incoming flow was abundant in nitrate $\left(5.2 \mathrm{~mol} \mathrm{~s}^{-1}\right.$; Table 3$)$.

Biological activity decreased slightly (Table 6) but was now represented to a great extent by diatoms (Figueiras \& Fraga 1990), as may be expected from water entering the ria from the exterior (Campos \& Gonzalez 1975).

The concentration of Gymnodinium catenatum was still very high as a result of accumulation, but at the station of analysis (Fig. 1), the value had decreased. The circulation carried it away to the exterior of the ria (Figs. $8 \& 9$ ).

The time needed to replenish the water in the upper layer was calculated as $15 \mathrm{~d}$ (Table 2) but this was dependent on environmental conditions. The winds and rains of the end of October (Fig. 1) brought about a new increase in the red tide (Fig. 1) due to new retention of water in the ria. The situation broke down definitively with the rains in November which created a rapid circulation, sufficient to totally replenish the water of the box in $8 \mathrm{~d}$, and $3.5 \mathrm{~d}$ in the upper layer (Prego \& Fraga in press).

The red tides of Gymnodinium catenatum recorded in the Ria of Vigo in 1976 (Estrada et al. 1984), 1985 (Fraga et al. 1988), and 1986 (Fraga \& Prego 1989, Figueiras \& Fraga 1990, Fraga et al. 1990) occurred under similar conditions in autumn, when the winds became southerly. The retention of water by certain wind patterns has already been considered by Conover (1954) as essential to red tide development in New Haven Harbor (Connecticut, USA).

The 4 phases indicated by Steidinger (1983) for the formation and breakdown of a red tide remain evident: (1) high production due to upwelling, (2) high remineralisation with availability of nutrient salts, (3) concentration of Gymnodinium catenatum sufficient to cause a red tide, and (4) final washing out of the ria by winter conditions.

The formation of a recirculation cell initiates the conditions of nutrient salt contribution and stability required by the model of Margalef (1978) for the formation of a red tide. The fluxes and consumptions of nutrient salts and particulate organic carbon for 4 and 21 September are given in Fig. 10.

\section{APPENDIX 1}

\section{Correction to phosphate balance}

The results of the flux balance for phosphate, A and B in Table 4, include processes different from those of photosynthesis, $\mathrm{P}$, or remineralisation, $\mathrm{R}$, as indicated
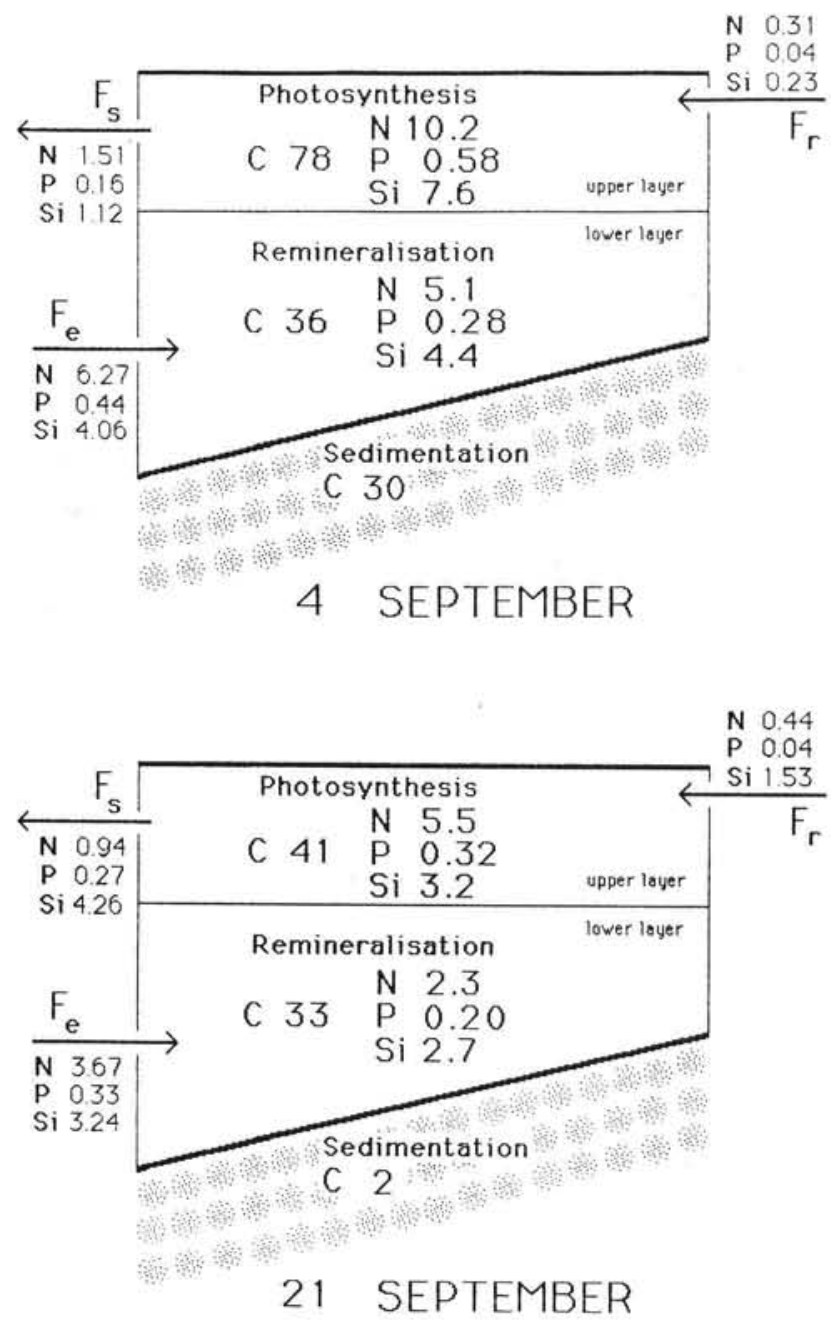

Fig. 10. Summary of the fluxes and budgets of nutrient salts in the box under consideration in the Ria of Vigo: inorganic nitrogen $(\mathrm{N})$, phosphate $(\mathrm{P})$, silicate $(\mathrm{Si})$ and particulate organic carbon (C) for 4 September (high production due to upwelling) and 21 September (high remineralisation and red tide). $F_{e}$ and $F_{s}$ : incoming and outgoing fluxes; $F_{r}$ : flux caused by freshwater. Units in mol s$~^{-1}$ box $^{-1}$

in 'Results'. The precipitation or redissolution of phosphates in the upper, $\mathrm{K}_{\mathrm{s}}$, and lower, $\mathrm{K}_{\mathrm{p}}$, layers must be treated as follows:

$$
\begin{aligned}
& A=K_{s}+P \\
& B=K_{p}-R
\end{aligned}
$$

To determine $\mathrm{P}$ and $\mathrm{R}$ it is necessary to known $\mathrm{K}_{\mathrm{s}}$ and $\mathrm{K}_{\mathrm{p}}$. This is done by taking PO, a parameter independent from that of photosynthesis and remineralisation. When selecting a component of each part of Eq. (3), i.e. $\mathrm{O}_{2}$ and $\mathrm{NO}_{3}{ }^{-}$or $\mathrm{HPO}_{4}{ }^{2-}$, and considering the quotients of the stoichometric coefficients (175:17 for the nitrate and $175: 1$ for the phosphate), the resulting parameter (NO or PO) is independent of Eq. (3), i.e. it is unaffected 
by photosynthesis and remineralisation processes. This parameter will be, in common with the NO parameter, conservative, as indicated by Broecker (1974).

The parameters PO and NO (Prego 1989, Rios et al. 1989) are defined as:

$\mathrm{PO}=175\left[\mathrm{HPO}_{4}{ }^{2-}\right]+\left[\mathrm{O}_{2}\right]-0.5\left[\mathrm{NO}_{2}^{-}\right]-2\left[\mathrm{NH}_{4}{ }^{+}\right]$
$\mathrm{NO}=10.29\left[\mathrm{~N}_{\mathrm{in}}\right]+\left[\mathrm{O}_{2}\right]-0.5\left[\mathrm{NO}_{2}^{-}\right]-2\left[\mathrm{NH}_{4}^{+}\right]$

where $\left[\mathrm{N}_{\mathrm{in}}\right]=\left[\mathrm{NO}_{3}^{-}\right]+\left[\mathrm{NO}_{2}^{-}\right]+\left[\mathrm{NH}_{4}^{+}\right]$.

In Eq. (3), nitrate is considered although both nitrite or ammonium may be present in seawater. Both are related to nitrate by the equations:

$\mathrm{NO}_{2}^{-}+0.5 \mathrm{O}_{2} \rightarrow \mathrm{NO}_{3}^{-}$

$\mathrm{NH}_{4}^{+}+2 \mathrm{O}_{2}+2 \mathrm{CO}_{3}^{2-} \rightarrow \mathrm{NO}_{3}^{-}+2 \mathrm{HCO}_{3}^{-}+\mathrm{H}_{2} \mathrm{O}$

For this reason, a correction $\left(-0.5\left[\mathrm{NO}_{2}^{-}\right]-2\left[\mathrm{NH}_{4}^{+}\right]\right)$is necessary for the parameters PO and NO defined by Eqs. (6) and (7).

PO will only vary through interchange with oxygen from the atmosphere or through the inorganic processes of flocculation or redissolution. On this basis, it is possible to write the equation:

upper layer: $\quad \mathrm{A}_{\mathrm{PO}}=+\mathrm{Og}+175 \mathrm{~K}_{\mathrm{s}}$

lower layer: $\quad \mathrm{B}_{\mathrm{PO}}=175 \mathrm{~K}_{\mathrm{p}}$

where $A_{P O}$ and $B_{P O}$ are the result of the balance $P O$ in the upper and lower layers, respectively, and $K_{\mathrm{s}}$ and $\mathrm{K}_{\mathrm{p}}$ the phosphate that appears and disappears by non- biological processes. The term $\mathrm{O}_{\mathrm{g}}$ is the oxygen interchanged with the atmosphere which is zero in the lower layer.

To determine $\mathrm{K}_{\mathrm{s}}$, it is necessary to make a prior calculation of $\mathrm{O}_{\mathrm{g}}$. Due to the fact that inorganic nitrogen is not involved in processes of precipitation-redissolution, the balance for NO in the upper layer is:

$$
\mathrm{A}_{\mathrm{NO}}=\mathrm{O}_{\mathrm{g}}
$$

As with the other balances, the data of measured seawater flows (Table 2) and oxygen and nutrient salts concentration (Prego et al. 1988) are used to calculate the fluxes of NO (Table 7), and the passage of oxygen, $\mathrm{O}_{\mathrm{g}}$, between air and water is determined (Table 7). Similarly, the data necessary to resolve Eqs. (10) and (11) are given in Table 7 . From these data the values for phosphate consumption during photosynthesis or remineralization are obtained by Eqs. (4) and (5). These are presented in Table 7 .

\section{APPENDIX 2}

\section{Correction to inorganic carbon balance and calcula- tion of fall and sedimentation of particulate organic carbon}

The values for the photosynthesis and remineralisation of carbon, which complement the results of the nutrient salts, are obtained by applying the system

Table 7. Data for solving Eqs. (4), (5), (10), (11) and (12) and results. Units for the fluxes F (letters refer to Fig. 2) and balances Apo. $\mathrm{B}_{\mathrm{PO}}$ and $\mathrm{A}_{\mathrm{NO}}$ are in mol $\mathrm{O}_{2} \mathrm{~s}^{-1}$ box ${ }^{-1}$; and for flocculation $(+)$ or redissolution (-) of phosphates, $\mathrm{K}_{\mathrm{S}}$ (upper layer) and $\mathrm{K}_{\mathrm{P}}$ (lower layer), and photosynthesis and remineralization are in mol $\mathrm{P} \mathrm{s}^{-1}$ box $^{-1}$. From the fluxes of NO are calculated the interchange of oxygen with the atmosphere $\mathrm{O}_{\mathrm{g}}$. A negative value means its entrance into the ria. The data of the balance of phosphate, $\mathrm{A}$ and $\mathrm{B}$ in Eqs. (4) and (5), are in Table 4

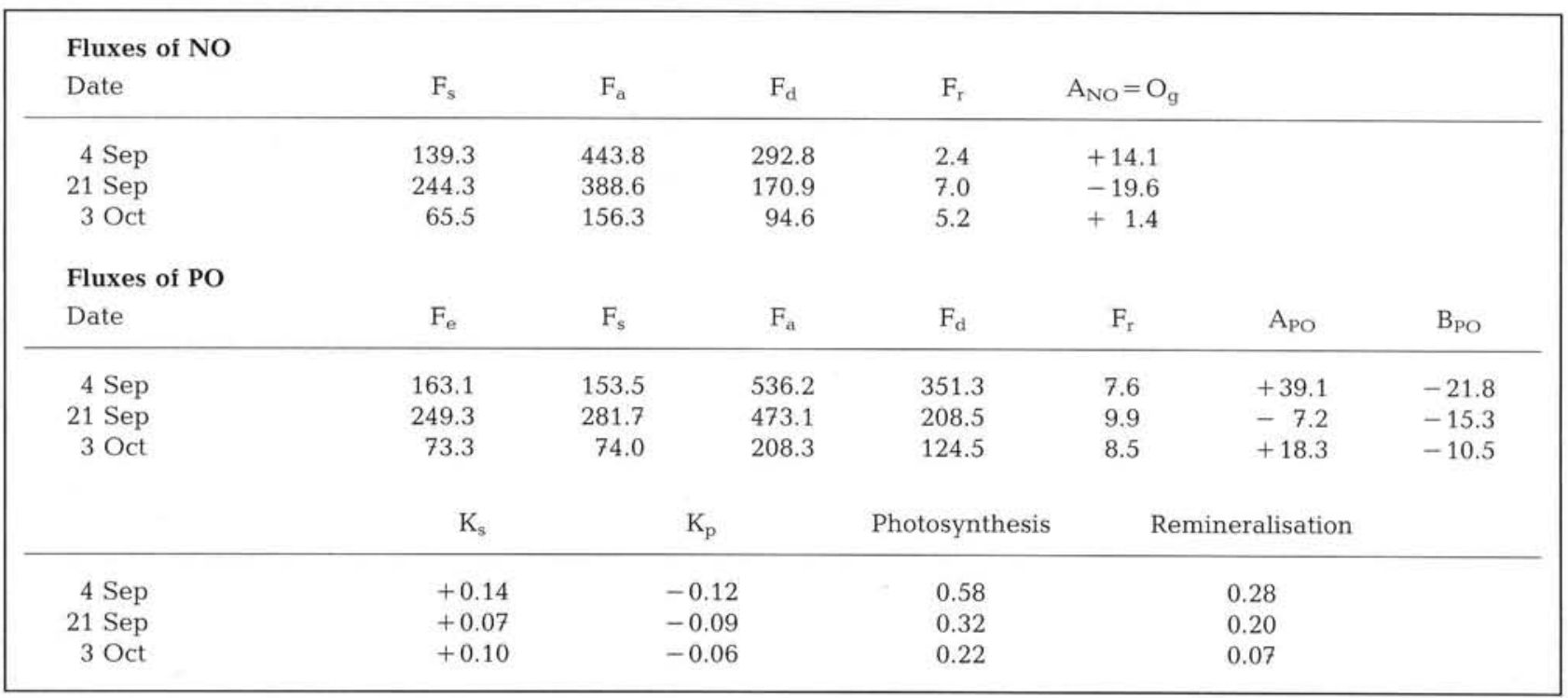


Table 8. Data for solving Eqs. (13) to (19) and their results. Units of $\mathrm{A0}$ in $\mathrm{mol} \mathrm{O}_{2} \mathrm{~s}^{-1}$ box $^{-1}$; rest in $\mathrm{mol} \mathrm{C} \mathrm{s}^{-1}$ box ${ }^{-1}$. C: $\mathrm{CO}_{2}$ which arrives ( - ) from the atmosphere; Cs and Cd: precipitation (+) or redissolution ( - ) of carbonates in the upper and lower layers; $\mathrm{P}$ : consumption of carbon in photosynthesis; D and S: fall and sedimentation of particulate carbon; R: remineralisation of organic carbon; see Fig. 11

\begin{tabular}{|rccccccccccccccc}
\hline Date & A0 & A1 & B1 & A2 & B2 & A3 & B3 & C & Cs & Cd & P & D & R & S \\
\hline 4 Sep & -3.1 & +59.8 & -32.4 & -28.2 & +16.9 & -17.0 & +11.0 & -12.7 & -5.1 & -3.9 & 77.6 & 49.4 & 36.3 & 30.0 \\
21 Sep & -21.0 & +43.3 & -23.4 & -9.8 & +4.0 & +9.1 & +17.6 & -1.0 & +3.1 & +9.6 & 41.2 & 31.4 & 33.0 & 2.4 \\
3 Oct & +4.0 & +33.8 & -15.0 & -8.4 & -0.8 & +6.1 & -5.3 & +1.9 & +3.2 & -2.1 & 28.7 & 20.3 & 12.9 & 6.6 \\
\hline
\end{tabular}

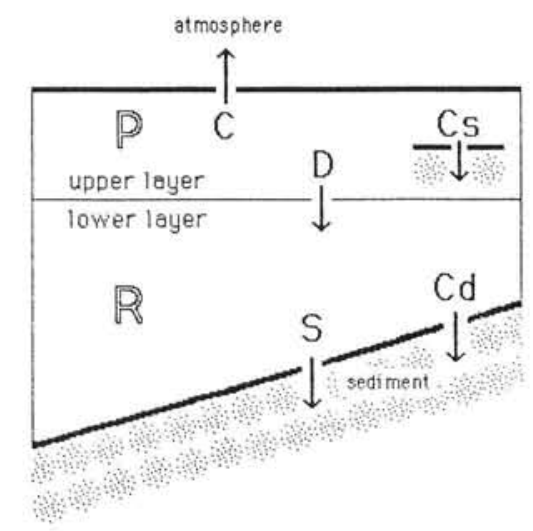

Fig. 11. Carbon interchanges in the box of ria: photosynthesis (P), fall (D), remineralisation (R) and sedimentation (S) of particulate organic carbon; precipitation or redissolution of carbonate in the upper $\left(\mathrm{C}_{\mathrm{s}}\right)$ and lower $\left(\mathrm{C}_{\mathrm{d}}\right)$ layer; and air-water transfer of $\mathrm{CO}_{2}$. Direction of arrows indicates a positive interchange

suggested by Prego (1989) and Prego (unpubl.) to the biogeochemical cycle of carbon.

In the box considered (Fig. 2), 7 interchanges of carbon take place, as shown in Fig. 11. In order to calculate them, the following set of 7 equations must be solved (A0, A1 etc. are defined below, and remaining terms in Fig. 11 legend):

$$
\begin{aligned}
& \mathrm{A} 0=+\mathrm{O}_{\mathrm{g}}+1.36 \mathrm{C} \\
& \mathrm{A} 1=+\mathrm{C}+\mathrm{C}_{\mathrm{s}}+\mathrm{P} \\
& \mathrm{B} 1=+\mathrm{C}_{\mathrm{d}}-\mathrm{R} \\
& \mathrm{A} 2=-\mathrm{P}+\mathrm{D} \\
& \mathrm{B} 2=+\mathrm{R}-\mathrm{D}+\mathrm{S} \\
& \mathrm{A} 3=-\mathrm{PN}+2 \mathrm{C}_{\mathrm{s}} \\
& \mathrm{B} 3=+\mathrm{RN}+2 \mathrm{C}_{\mathrm{d}}
\end{aligned}
$$

Eq. (13) is considered as a CAO balance. It is similar to that made for $\mathrm{NO}$ in Eq. (12). CAO, in the same way as for NO and PO in Appendix 1, is a conservative parameter (Prego 1989) defined as:

$$
\begin{aligned}
& \mathrm{CAO}= \\
& {\left[\mathrm{O}_{2}\right]+1.36\left(\left[\mathrm{CO}_{2}\right]-\mathrm{C}_{\mathrm{ar}}\right)-0.5\left[\mathrm{NO}_{2}^{-}\right]-2\left[\mathrm{NH}_{4}^{+}\right]}
\end{aligned}
$$

where $\mathrm{C}_{\mathrm{ar}}=0.5\left(\mathrm{Alk}+\left[\mathrm{NO}_{3}^{-}\right]-0.45\left[\mathrm{NO}_{2}^{-}\right]-\right.$ $\left.2\left[\mathrm{NH}_{4}^{+}\right]\right)$. Its correction is due to the consumption of carbonate in the formation of the skeleton of some marine organisms, which is reflected in the alkalinity (Alk). The air-water interchange of $\mathrm{CO}_{2}, \mathrm{C}$, must be considered. This is converted from mol C s ${ }^{-1}$ box $^{-1}$ to mol $\mathrm{O}_{2} \mathrm{~s}^{-1}$ box ${ }^{-1}$, units of $\mathrm{A} 0$ and $\mathrm{O}_{\mathrm{g}}$ (oxygen interchange, Eq. (12)), with the factor $1.36(175: 129$, the O:C quotient in Eq. (3)).

Eqs. (14) and (15), the inorganic carbon balance, are similar to those of (4) and (5), also including the airwater interchange of $\mathrm{CO}_{2}$.

Eqs. (16) and (17), the organic carbon balance, take into consideration photosynthesis, remineralisation and the fall and sedimentation of organic carbon.

Eqs. (18) and (19), the alkalinity balance, arise from the appearance and disappearance of strong ions in the interchange shown in Fig. 11. The consumption of ammonia and the precipitation of carbonate decrease the value of alkalinity balance and the consumption of nitrate and nitrite will increase it. This is considered in the terms PN and RN.

Data for the balances of CAO in the upper layer (A0), and the inorganic and organic carbon and the alkalinity in the upper layer (A1, A2, A3) and lower layer (B1, B2, B3) are presented in Table 8. The value for $\mathrm{O}_{\mathrm{g}}$ is in Table 7 and $\mathrm{PN}$ and $\mathrm{RN}$ are the consumption or remineralization of nitrates plus nitrites less ammonium, calculated from the data of Table 3. The results from Eqs. (13) to (19) are in Table 8.

Acknowledgements. I gratefully acknowledge the assistance and valuable comments on the manuscript provided by Drs Marta Estrada and Peter Wangersky. I am also indebted to the 'Centro Meteorologico Zonal de La Coruña' for meteorological data, and to the I.E.O. of Vigo for their kind invitation to their workshop, which served as an introduction for me to the study of red tides. Special thanks to Prof. Fernando Fraga, head of the project 'Intercambio de nutrientes entre las rias y la plataforma costera en el NO de la península Ibérica', from which we obtained data for this paper. Thanks are also due to Ian Emmett for revision of the English text.

\section{LITERATURE CITED}

Aston, S. R. (1980). Nutrients, dissolved gases, and general biogeochemistry in estuaries. In: Olausson, E., Cato, I. (eds.). Chemistry and biogeochemistry of estuaries. Wiley, Chichester, p. 233-262 
Beer, T. (1983). Environmental oceanography. Pergamon Press, Oxford

Broecker, W. S. (1974). 'NO', a conservative water-mass tracer. Earth planet. Sci. Lett. 23: 100-107

Campos, M. J., Gonzalez, N. (1975). Phytoplankton in relation with nutrient concentration in the Ria de Arosa. In: Persoone, G., Jaspers, E. (eds.) Proc. 10th Eur. Mar. Biol. Symp., Vol 2. Universa Press, Wetteren, p. 111-126

Chang, J., Carpenter, E. J. (1985). Blooms of the dinoflagellate Gyrodinium aureolum in a Long Island estuary: box model analysis of bloom maintenance. Mar. Biol. 89: 83-93

Cohen, R. R. H. (1985). Physical processes and the ecology of a winter dinoflagellate bloom of Katodinium rotundatum. Mar. Ecol, Prog. Ser. 26: 135-144

Conover, S. M. (1954). Observations on the structure of red tides in New Haven harbor, Connecticut. J. mar. Res. 13: 145-155

Cullen, J. J., Horringan, S. G. (1981). Effects of nitrate on the diurnal vertical migration, carbon to nitrogen ratio and the photosynthetic capacity of the dinoflagellate Gymnodinium splendens. Mar. Biol. 62: 81-89

Cullen, J. J. (1985). Diel vertical migration by dinoflagellates: roles of carbohydrate metabolism and behavioral flexibility. In: Rankin, M. A. (ed.) Migration: mechanisms and adaptative significance. Mar. Sci. Inst., Univ. Texas, Mar. Sci. suppl. 27: 135-152

Dortch, Q., Maske, H. (1982). Dark uptake of nitrate and nitrate reductase activity of a red tide population off Peru. Mar. Ecol. Prog. Ser. 9: 299-303

Eppley, R. W., Harrison, W. G. (1975). Physiological ecology of Gonyaulax polyedra, a red water dinoflagellate of southern California. In: LoCicero, V. R. (ed.) Proc. 1st int. Conf. Toxic dinoflagellate blooms. Massachusetts Science and Technology Foundation, Wakefield, p. 11-22

Eppley, R. W., Koeller, P., Wallace, G. T. (1978). Stirring influences the phytoplankton species composition within enclosed columns of coastal seawater. J. exp. mar. Biol. Ecol. 32: 219-239

Estrada, M., Sánchez, F. J., Fraga, S. (1984). Gymnodinium catenatum (Graham) en las rías gallegas (NO de España). Invest. Pesq. 48: 31-40

Figueiras, F. G. (1989). Formación y mantenimiento de las purgas de mar en las Rías Bajas. In: Fraga, F., Figueiras, F. G. (eds.) Las purgas de mar como fenómeno natural. Las mareas rojas. Cuadernos da Area de Ciencias Mariñas, Vol, 4. Edicios do Castro, La Coruña, p. 73-84

Figueiras, F. G., Fraga, F. (1990). Vertical nutrient transport during proliferation of Gymnodinium Catenatum Graham in ria of Vigo, Northwest Spain. In: Granéli, E., Sundström, B., Edler, L., Anderson, D. M. (eds.). Toxic marine phytoplankton. Proc. Fourth Int. Conf. on Toxic Marine Phytoplankton, June 26-30, 1989, Lund, Sweden. Elsevier, New York, p. 144-148

Fraga, S., Anderson, D. M., Bravo, I., Reguera, B., Steidinger, A., Yentsch, C. M. (1988). Influence of upwelling relaxation on dinoflagellates and shellfish toxicity in Ria de Vigo, Spain. Estuar. coast. Shelf Sci. 27: 349-361

Fraga, F., Prego, R. (1989). Condicciones hidrográficas previas a la purga de mar. In: Fraga, F., Figueiras, F. G. (eds.) Las purgas de mar como fenómeno natural. Las mareas rojas. Cuadernos da Area de Ciencias Mariñas, Vol 4. Edicios do Castro, La Coruña, p. 21-44

Fraga, S., Reguera, B., Bravo, I. (1990). Gymnodinium catenatum bloom formation in the Spanish rias. In: Granéli, E., Sundström, B., Edler, L., Anderson, D. M. (eds.) Toxic marine phytoplankton. Proc. Fourth Int. Conf. on Toxic Marine Phytoplankton, June 26-30, 1989, Lund, Sweden. Elsevier, New York, p. 149-154
Grasshoff, K., Johannsen, H. (1972). A new sensitive and direct method for the automatic determination of ammonia in sea water. J. Cons. int. Explor. Mer. 34: 516-521

Hansen, H. P., Grasshoff, K. (1983). Automated chemical analysis. In: Grasshoff, K., Ehrhardt, M., Kremling, K. (eds.) Methods of seawater analysis. Verlag Chemie, Weinhein, p. 368-376

Harrison, W. G. (1973). Nitrate reductase activity during a dinoflagellate bloom. Limnol. Oceanogr. 18: 457-465

Holligan, P. M., Williams, P. J. le B., Purdie, D., Harris, R. P. (1984). Photosynthesis, respiration, and nitrogen supply of plankton populations in stratified, frontal and tidally mixed shelf waters. Mar. Ecol. Prog. Ser. 17: 201-213

Huntsman, S. A., Sunda, W. G. (1980). The role of trace metals in regulating phytoplankton growth, with emphasis on $\mathrm{Fe}, \mathrm{Mn}$ and $\mathrm{Cu}$. In: Morris, I. (ed.) The physiological ecology of phytoplankton. Blackwell Sci. Publ., Boston, p. 285-328

Lindahl, O. (1983). On the development of a Gyrodinium aureolum ocurrence on the Swedish west coast in 1982. Mar. Biol. 77: 143-150

Luthy, J. (1979). Epidemic paralytic shellfish poisoning in western Europe, 1976. In: Taylor, D. L., Seliger, H. H. (eds.) Toxic dinoflagellate blooms. Elsevier, New York, p. $15-22$

MacIsaac, J. J. (1978). Diel cycle of inorganic nitrogen uptake in a natural phytoplankton population dominated by Gonyaulax polyedra. Limnol. Oceanogr. 23: 1-9

Margalef, R. (1956). Estructura y dinámica de la purga de mar en la ría de Vigo. Invest. Pesq. 5: 113-134

Margalef, R. (1978). Life-forms of phytoplankton as survival alternatives in an unstable environment. Oceanol. Acta 1: 493-509

Margalef, R. (1989). Condicciones de aparición de la purga de mar y presiones de selección sobre sus componentes. In: Fraga, F., Figueiras, F. G. (eds.) La purga de mar como fenómeno natural. Las mareas rojas. Cuadernos da Area de Ciencias Mariñas, Vol. 4. Edicios do Castro, La Coruña, p. $13-20$

Margalef, R., Duran, M., Saiz, F. (1955). El fitoplancton de la ría de Vigo de enero de 1953 a marzo de 1954 . Invest. Pesq. 2: 85-129

Margalef, R., Estrada, M., Blasco, D. (1979). Functional morphology of organisms involved in red tides, as adapted to decaying turbulence. In: Taylor, D. L., Seliger, H. H. (eds.) Toxic diniflagellate blooms. Elsevier, New York, p. 89-94

Mouriño, C., Fraga, F. (1985). Determinación de nitratos en agua de mar. Invest. Pesq, 49: 81-96

Mouriño, C., Fraga, F., Fernández Pérez, F. (1984). Hidrografía de la ría de Vigo. In: As rías galegas. Cuadernos da Area de Ciencias Mariñas, Vol 1. Edicios do Castro, La Coruña, p. 91-103

Prego, R. (1989). Intercambio de sales nutrientes entre cuerpos de agua oceánicos, seguido por métodos químicos. Ph.D. thesis. Servicio de Publicaciones e Intercambio Científico. University of Santiago de Compostela

Prego, R., Fraga, F. (1988). A colorimetric method for the determination of organic carbon in sea water. Invest. Pesq. 52: $421-435$

Prego, R., Fraga, F. (in press). A simple model to calculate the residual flows in a Spanish ria. Hydrographic consequences in the ria of Vigo. Estuar. coast. Shelf. Sci.

Prego, R., Pérez, F. F., Ríos, A. F., Fraga, F., Figueiras, F. F. (1988). Datos hidrográficos de la ría de Vigo: 1986. Datos Informativos, 23. Inst, Inv. Marinas, Vigo 
Prego, R., Fraga, F., Rios, A. F. (1990). Water interchange between the Ria of Vigo and the coastal shelf. Scient. Mar. 54: $95-100$

Rios, A. F., Fraga, F. (1987). Composición química elemental del plancton marino. Invest. Pesq. 51: 619-632

Rios, A. F., Fraga, F., Pérez, F. F. (1989). Estimation of coefficients for calculation of ' $\mathrm{NO}$ ', 'PO' and ' $\mathrm{CO}$ ', starting from the elemental composition of natural phytoplankton. Scient. Mar. 53: 779-784

Siegel, A. (1971). Organic compounds and the aquatic environment. Faust, S. P., Hunter, J. V. (eds.) Dekker, New York, p. 265-295

Slobodkin, L. B. (1953). A possible initial condition for red tides on the coast of Florida. J. mar. Res. 1: 148-155

Smayda, T. J. (1990). Novel and nuisance phytoplankton blooms in the sea: evidence for a global epidemic. In:

This article was presented by P. J. Wangersky, Halifax, N. S., Canada
Granéli, E., Sundström, B., Edler, L., Anderson, D. M. (eds.) Toxic marine phytoplankton. Proc. Fourth Int. Conf. on Toxic Marine Phytoplankton, June 26-30, 1989, Lund, Sweden. Elsevier, New York, p. 29-40

Sobrino, R. (1918). La purga de mar o hematotalasia. Mem. R. Soc. Esp. Hist. Nat. 10: 407-458

Steidinger, K. A. (1983). A re-evaluation of toxic dinoflagellate biology and ecology. Prog. Phycol. Res. 2: 147-188

Tangen, K. (1977). Blooms of Gyrodinium aureolum (Dynophiceas) in north European waters, accompained by mortality in marine organisms. Sarsia $63: 123-133$

Vives, F., Fraga, F. (1961). Producción básica en la ría de Vigo (NW de España). Invest. Pesq. 19: 129-137

Yamochi, S., Abe, T. (1984). Mechanisms to initiate a Heterosigma akashiwo red tide in Osaka Bay. II. Diel vertical migration. Mar. Biol. 83: 255-261

Manuscript first received: February 14, 1991

Revised version accepted: November 27, 1991 